\title{
Activin A, exendin-4, and glucose stimulate differentiation of human pancreatic ductal cells
}

\author{
Hyo-Sup Kim*, Seung-Hyun Hong ${ }^{1, *}$, Seung-Hoon Oh, Jae-Hyeon Kim, Myung-Shik Lee \\ and Moon-Kyu Lee
}

Division of Endocrinology and Metabolism, Department of Medicine, Sungkyunkwan University School of Medicine, Samsung Biomedical Research Institute (SBRI), Samsung Medical Center, \#50 Ilwon-dong, Kangnam-ku, Seoul 135-710, Republic of Korea

${ }^{1}$ Korea Research Institute of Bioscience and Biotechnology, Aging Research Center, Daejeon 305-806, Republic of Korea

*(H-S Kim and S-H Hong contributed equally to this work)

\author{
Correspondence \\ should be addressed \\ to M-K Lee \\ Email \\ leemk@skku.edu
}

\begin{abstract}
Islet transplantation is one treatment option for diabetes mellitus. However, novel sources of pancreatic islets or insulin-producing cells are required because the amount of donor tissue available is severely limited. Pancreatic ductal cells are an alternative source of $\beta$-cells because they have the potential to differentiate into insulin-producing cells. We investigated whether treatment of human pancreatic ductal cells with activin A (ActA) and exendin-4 (EX-4) stimulated transdifferentiation of the cells, both in vitro and in vivo. We treated human pancreatic ductal cells with ActA and EX-4 in high-glucose media to induce differentiation into insulin-producing cells and transplanted the cells into streptozotocin-induced diabetic nude mice. Co-treatment of mice with ActA and EX-4 promoted cell proliferation, induced expression of pancreatic $\beta$-cell-specific markers, and caused glucose-induced insulin secretion compared with the ActA or EX-4 mono-treatment groups respectively. When pancreatic ductal cells treated with ActA and EX-4 in high-glucose media were transplanted into diabetic nude mice, their blood glucose levels normalized and insulin was detected in the graft. These findings suggest that pancreatic ductal cells have a potential to replace pancreatic islets for the treatment of diabetes mellitus when the ductal cells are co-treated with ActA, EX-4, and glucose to promote their differentiation into functional insulin-producing cells.
\end{abstract}

Key Words

- Activin A

- Exendin-4

- Glucose

- Human pancreatic ductal cells

- Differentiation

\section{Introduction}

One of the major determinants of both type 1 and type 2 diabetes mellitus is loss of $\beta$-cell mass or dysfunction in the pancreas. Transplantation of an entire pancreas or pancreatic islets is an effective method to treat diabetes. However, there is a severe shortage of available donor tissue. Most studies have demonstrated that the growth capacity of islets in vitro is limited (Brelje et al. 1993).
Moreover, culture of human adult islets requires preparation of an extracellular matrix and several growth factors. However, most of the growth protocols for islets result in a decrease in the insulin-producing capacity of the islets (Yuan et al. 1996, Lefebvre et al. 1998, Beattie et al. 1999). Other sources of $\beta$-cells, such as embryonic stem cells, bone marrow stem cells, pancreatic acinar cells, http://joe.endocrinology-journals.org DOI: 10.1530/JOE-12-0474
(C) 2013 Society for Endocrinology Printed in Great Britain 
pancreatic duct epithelium cells (ductal cells), and pancreatic stem or progenitor cells, have been shown to be able to differentiate into insulin-producing cells (Bonner-Weir et al. 2004, Bonner-Weir \& Weir 2005, Yue et al. 2006). Among these, human pancreatic ductal cells have the advantage that they can be harvested from pancreatic remnants after islet isolation.

Activin A (ActA) is a member of the transforming growth factor $\beta$ superfamily, and it regulates the proliferation and differentiation of many types of cells (Hemmati-Brivanlou \& Melton 1994) as well as embryonic axial patterning and the functions of foregut-derived organs (Moriya et al. 2000). Moreover, ActA can promote pancreatic bud formation, facilitate the differentiation of endocrine and exocrine cells in the pancreas, and induce the formation of pancreatic islets (Yamaoka et al. 1998). ActA has been reported to induce amylase-secreting pancreatic exocrine cell lines to differentiate into pancreatic polypeptide-producing endocrine cells (Mashima et al. 1996). Furthermore, injection of ActA with betacellulin reduced hyperglycemia in neonatal streptozotocin (STZ)-induced diabetic rats (Li et al. 2004). ActA is also needed at relatively early stages of the differentiation of embryonic stem cells, and it promotes induced pluripotent stem cells to change into endocrine cells (Tateishi et al. 2008, Maehr et al. 2009, Zhang et al. 2009). We previously reported that ActA could potentiate the differentiation of rat pancreatic ductal cells (Park et al. 2007). Therefore, we hypothesized that ActA might have the potential to stimulate both the growth and differentiation of pancreatic ductal cells.

Glucagon-like peptide-1 (GLP1) is an intestinal insulinotropic hormone that is secreted from L-cells of the distal ileum and colon (Drucker 1998). GLP1 administration in patients with type 2 diabetes mellitus can decrease their glucose levels (Gutniak et al. 1992, Nauck et al. 1993, Thorens et al. 1993). Moreover, GLP1 increases the $\beta$-cell mass by inducing the differentiation and neogenesis of ductal cells into insulin-producing cells through regulation of PDX1 expression (Mojsov et al. 1987, Knudsen \& Pridal 1996, Todd et al. 1997, Drucker 2002, Sudre et al. 2002). The GLP1 analog, exendin-4 (EX-4), is a potent insulinotropic molecule with a much longer half-life (Goke et al. 1993, Thorens et al. 1993, Chen \& Drucker 1997). Injection of EX-4 was shown to have long-term beneficial effects on blood glucose levels in diabetic mice and rat (Greig et al. 1999) and induced the expression of the GLP1 receptor in pancreatic ducts and $\beta$-cell replication (Xu et al. 1999, Tourrel et al. 2001). These results suggest that EX-4 has the potential to induce the differentiation of ductal cells into insulin-producing cells. In this study, we investigated for the first time the possibility that human pancreatic ductal cells may be a useful $\beta$-cell source in a diabetic animal model, and we determined the effects of ActA and EX-4 treatment on the differentiation of human pancreatic ductal cells.

\section{Materials and methods}

\section{Isolation of human islets}

Human pancreatic islets were isolated by organ distension using intraductal collagenase (Boehringer Mannheim) and digested using a modified automated method (Ricordi et al. 1988). Islet purification was performed with a COBE 2991 processor (COBE, Lakewood, CA, USA) and a largescale continuous density gradient (Robertson et al. 1993) prepared from Ficoll-diatrizoate media using the pancreatic digests from cadavers $(n=5)$. Islet purity was determined subjectively by visual assessment using two $100 \mu \mathrm{l}$ sampling strips. Islet yields were expressed as islet equivalents (of islets $150 \mu \mathrm{m}$ in diameter) (Ricordi et al. 1990). After islet isolation, purified islets were incubated for at least $24-48 \mathrm{~h}$ at $37^{\circ} \mathrm{C}$ in culture medium.

\section{Culture of human pancreatic ductal cells}

After human pancreatic islet isolation for transplantation, residual cells were collected and plated in M199 media (Hyclone, Logan, UT, USA) supplemented with 10\% fetal bovine serum (Gibco) in a T-175 culture flask at $37^{\circ} \mathrm{C}$ in an incubator. Geneticin $(50 \mu \mathrm{M})$ (G418; Cellgro, Manassas, VA, USA) was added to inhibit fibroblast proliferation. After 2 days, cells were dissociated with cell dissociation kit (Sigma) and plated on appropriate plates. To remove residual $\beta$-cells, $5 \mathrm{mM}$ STZ (Sigma) in growth media were added to the cells followed by a 5-day incubation. The $5 \mathrm{mM}$ STZ containing M199 media were changed every day. Then, the human ductal cells were treated with 2 nM ActA (R\&D Systems, Minneapolis, MN, USA) and $10 \mathrm{nM}$ EX-4 (Sigma) in $11 \mathrm{mM}$ glucose containing M199 media. The use of human pancreatic islets and ductal cells was approved by Samsung Medical Center Institutional Review Board (IRB number; SMC 2005-11-013-007).

\section{Glucose-induced insulin secretion}

Differentiated human ductal cells $\left(1 \times 10^{5}\right)$ and 20 islets per well in a 24-well plate were washed with Krebs-Ringer bicarbonate HEPES (KRBH) buffer (pH 7.37) and incubated

Published by Bioscientifica Ltd 
for an additional $60 \mathrm{~min}$ in $1 \mathrm{ml} \mathrm{KRBH}$ buffer that contained 5.6 or $16.7 \mathrm{mM}$ glucose. Then, the media were stored at $-20^{\circ} \mathrm{C}$ until required for insulin determination. The concentration of secreted insulin was determined using a human insulin ELISA kit (Mercodia, Uppsala, Sweden).

\section{Analysis of gene expressions}

Total RNA from human ductal cells and islets was obtained using Trizol reagent (Invitrogen) according to the manufacturer's recommendation. First-strand cDNA was synthesized from $1 \mu \mathrm{g}$ total RNA using SuperScript First-Strand Synthesis System for RT-PCR (Invitrogen). This cDNA ( $5 \%$ of first RT reaction volume) was amplified directly by a quantitative PCR (q-PCR) system. q-PCR was performed with SYBR green PCR master mix (Applied Biosystems) and analyzed with the 7500 real-time PCR system (Applied Biosystems). Primer annealing temperatures were suggested by the manufacturer (Bioneer, Daejeon, Korea) and the primer sequences were as follows: cytokeratin-19 (CK19) (KRT19): CTTTTCGCGCGCCCAGCATT and GATCTTCCTGTCCCTCGAGC; NGN3 (NEUROG3): AGACGACGCGAAGCTCACC and AAGCCAGACTGCCTGGGCT; PDX1: CTGCCTTTCCCATGGATGAA and CGCTTCTTGTCCTCCTCCTTT; NEUROD (NEUROD1): ATCCCAACCCACCACCAACC and CAGCGGTGCCTGAGAAGATT; PREPROINSULIN: CATCAAGCACATTGTCC and CTGGTTCAAGGGCTTTATTC; INSULIN: GCAGCCTTTGTGAACCAACA and TCTGCGGTCATCAAATGAGG; NKX6.1 (NKX6-1): TCTTCTGGCCCGGGGTGATG and AGCCGCGTGCTTCTTCCTCC; GLUT2 (SLC2A2): CAAATCTGACTCCAAAGCTC and CTGTCTCTTGCAAGATCAGC; PAX4: AGGAGGACCAGGGACTACCGT and TTTAGGTGGGGTGTCACTCAG; PAX6: CAAAAGTCCAAGTGCTGGACA and CCCATCTGTTGCTTTTCGCT; GAPDH: AGAGCTATGAGCTGCCTGAC and CTGATCCACATCTGCTGGAA.

\section{Experimental animals and transplantation}

All procedures were performed in accordance with the recommendations in the Guide for the Care and Use of Laboratory Animals of the National Institutes of Health. The protocol was approved by the Committee on the Ethics of Animal Experiments of the Samsung Biomedical Research Institute (SBRI), Sungkyunkwan University School of Medicine (Permit Number: H-B0-043). For transplantation, male Balb/C-nude mice (Orientbio, Seongnam, Gyeonggi-do, Korea) were housed at a constant temperature $\left(23.5 \pm 2.0^{\circ} \mathrm{C}\right)$ and humidity $(50 \pm 5 \%)$ under a $12 \mathrm{~h}$ light: $12 \mathrm{~h}$ darkness cycle. At 6 weeks of age, diabetes was induced by a single i.p. administration of $200 \mathrm{mg} / \mathrm{kg}$ body weight (BW) of STZ dissolved in $0.05 \mathrm{mmol} / \mathrm{l}$ citrate buffer $(\mathrm{pH} 4.5)$. After verification of hyperglycemia for 1 week, the left kidney of the mouse was exposed through a small incision in the flank under inhalational isoflurane anesthesia. A small channel was made under the renal subcapsular space of the kidney with a 26 gauge needle. Human ductal cells $\left(1 \times 10^{6}\right)$ infected with $1 \times 10^{8} \mathrm{pfu} / \mathrm{ml}$ adenovirus-GFP were transplanted into the subcapsular space of the kidney. ActA was injected i.p. at $100 \mathrm{ng} / \mathrm{g}$ BW and EX-4 was injected s.c. at $3 \mathrm{ng} / \mathrm{g} \mathrm{BW}$. Blood glucose levels were determined using the Accu-Check Active System (Roche) every 2 days for 60 days. At 60 days after transplantation, transplant grafts were removed from mice and then blood glucose was measured for 8 days.

\section{Immunocytochemistry and immunohistochemistry}

The samples were washed three times in PBS and then fixed with $4 \%$ paraformaldehyde for $10 \mathrm{~min}$ at room temperature. After permeabilization with $0.5 \%$ Triton $\mathrm{X}-100$ for $15 \mathrm{~min}$ at room temperature, primary antibodies were added overnight at $4{ }^{\circ} \mathrm{C}$. After washing with PBS, secondary antibodies were added for $1 \mathrm{~h}$ at room temperature and DAPI (Dako, Glostrup, Denmark) was used for nuclear staining. The cells were then examined by fluorescence microscopy (Olympus). The primary antibodies we used were as follows: monoclonal mouse anti-CK19, polyclonal guinea pig anti-insulin (Dako), monoclonal mouse anti-carbohydrate antigen 19-9 (CA19-9) (Leica Biosystems, Nussloch, Germany), monoclonal mouse anti-BrdU, platelet/endothelial cell adhesion molecule (PECAM; Sigma), polyclonal rabbit anti-PDX1 (Abcam, Cambridge, MA, USA), and polyclonal anti-goat GLUT2 (Santa Cruz Biotechnology). Secondary antibodies were conjugated with FITC or Texas red (Vector, Burlingame, CA, USA).

\section{Apoptosis assay}

To monitor apoptosis in STZ-treated human ductal cells and the sectioned transplanted grafts and pancreas tissues, we performed the TUNEL assay with an in situ cell death detection kit (Roche) according to the manufacturer's recommendation. DNase I ( $3 \mathrm{U} / \mathrm{ml}$ ) (Roche) was added as a positive control and propidium iodide (Dako) was used to stain nuclei.

Published by Bioscientifica Ltd 


\section{Statistical analysis}

The data are presented as the means \pm s.D. Mann-Whitney $U$ tests were performed to compare the differences between two independent groups. One-way ANOVA with post hoc analyses was used to compare the differences between several groups. $P$ values $<0.05$ were considered statistically significant (PRISM; Graphpad Software Corp., San Diego, CA, USA).

\section{Results}

\section{Isolation and cultivation of human pancreatic ductal cells}

After human islet isolation for transplantation, residual cells were cultured in growth media containing $50 \mu \mathrm{M}$ geneticin for 2 days. Suspended cells were discarded, and attached cells were re-seeded in appropriate culture dishes. In this step, isolated cells were immunostained with CK19; only a
A

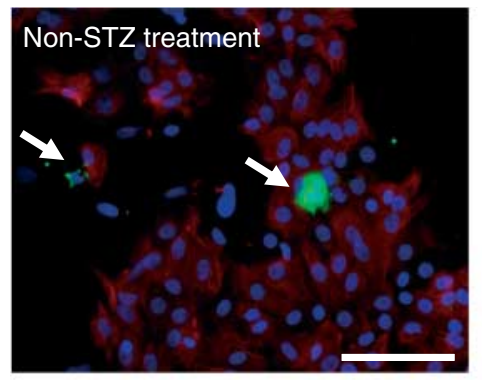

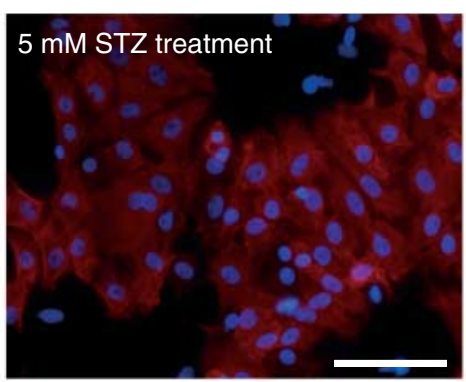

B
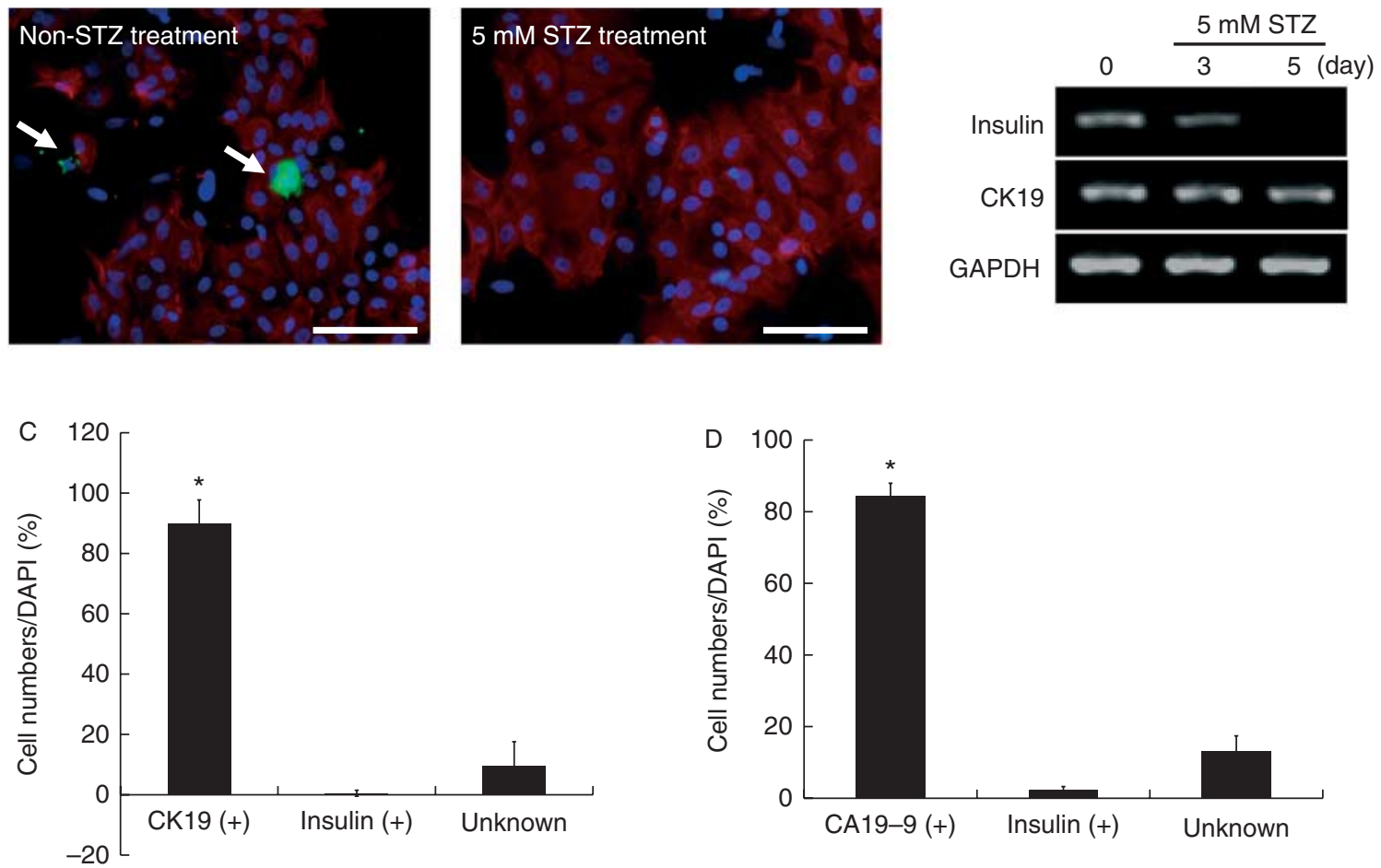

E
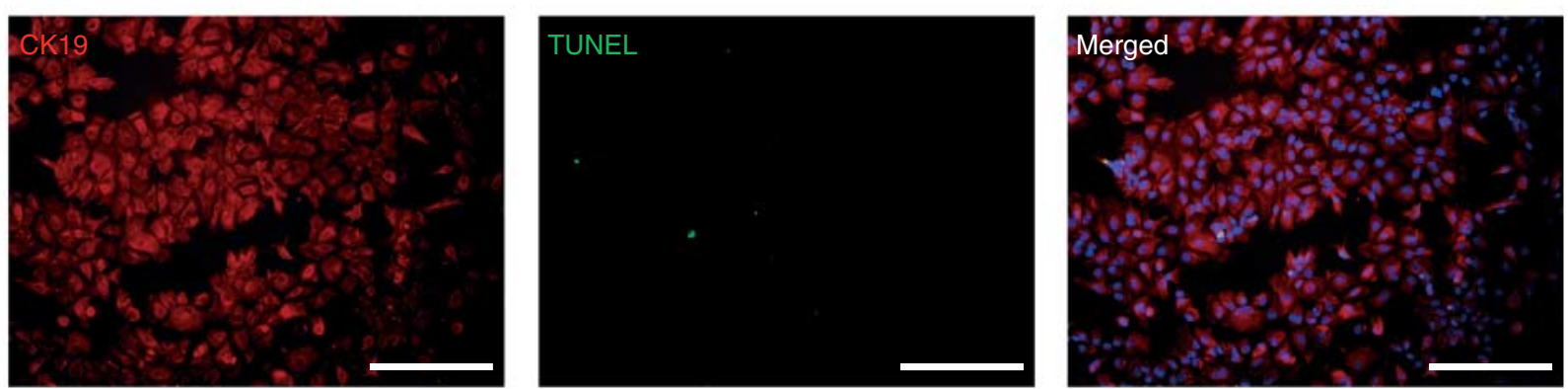

\section{Figure 1}

Characteristics of pure isolated human ductal cells. (A) During the initial stages of human ductal cell culture, CK19 (red)- and insulin (green)-positive cells were detected by immunostaining. Insulin-positive cells (arrow) were detected in the non-STZ treatment group (left). Treatment with $5 \mathrm{mM}$ STZ removed residual $\beta$-cells (right). $\times 400$, scale bar $=100 \mu \mathrm{m}$. (B) Insulin mRNA levels were decreased by STZ treatment. However, CK19 mRNA levels were not altered. (C and D) After completing geneticin and STZ treatment, we evaluated the purity of human ductal cells by CK19 and CA19-9 immunostaining. After immunostaining, the number of CK19-, CA19-9-, and insulin/DAPI-positive cells was counted (CK19: $89.9 \pm 7.84 \%$, insulin: $0.49 \pm 0.99 \%$, unknown: $9.6 \pm 7.97 \% ; n=4, * P<0.001$ vs insulin $(+)$, unknown) (CA19-9: $84.31 \pm 3.62 \%$, insulin: $2.48 \pm 0.79 \%$, unknown: $13.2 \pm 4.21 \% ; n=4, * P<0.001$ vs insulin ( + ), unknown). (E) A small number of TUNEL-positive cells were observed after STZ treatment. $\times 200$, scale bar $=200 \mu \mathrm{m}$ http://joe.endocrinology-journals.org DOI: $10.1530 / J O E-12-0474$
C 2013 Society for Endocrinology Printed in Great Britain 
few $\beta$-cells were detected among the human ductal cells (Fig. 1A). To remove residual $\beta$-cells and to further purify the human ductal cells, $5 \mathrm{mM} \mathrm{STZ}$ were added to the culture media for 5 days. After STZ treatment, insulin mRNA expression was decreased. However, CK19 mRNA expression was not altered (Fig. 1B). We monitored the expression of CK19 and CA19-9 as ductal cell-specific markers and found that the total proportion of CK19- and CA19-9-positive human ductal cells was more than 85\% (Fig. 1C and D). We performed an apoptosis assay to determine whether STZ induced cell death in human ductal cells. Small numbers of TUNEL-positive cells were detected (Fig. 1E).

\section{Effects of ActA and EX-4 on $\beta$-cell marker expression in human pancreatic ductal cells}

We measured the mRNA levels of pancreatic $\beta$-cell-specific markers over time. As shown in Fig. 2, $\beta$-cell-specific markers were not fully expressed at 10 days. Interestingly, co-treatment of cells with ActA and EX-4 induced the expression of $\beta$-cell-specific markers earlier than treatment of cells with $11 \mathrm{mM}$ high glucose (HG), ActA, or EX-4. At 10 days after co-treatment with ActA, EX-4, and HG, expression of $\beta$-cell-specific markers were increased, except GLUT2. Moreover, the ActA- and EX-4-co-treated ductal cells showed similar expression levels of these $\beta$-cell-specific markers compared with normal islets at 30 days of differentiation.

\section{Effects of ActA and EX-4 on the proliferation of human pancreatic ductal cells}

At 30 days of differentiation, co-treatment of cells with ActA and EX-4 induced more cell proliferation than was seen in the other treatment groups (Fig. 3A). Replication of human ductal cells was monitored by the BrdU uptake
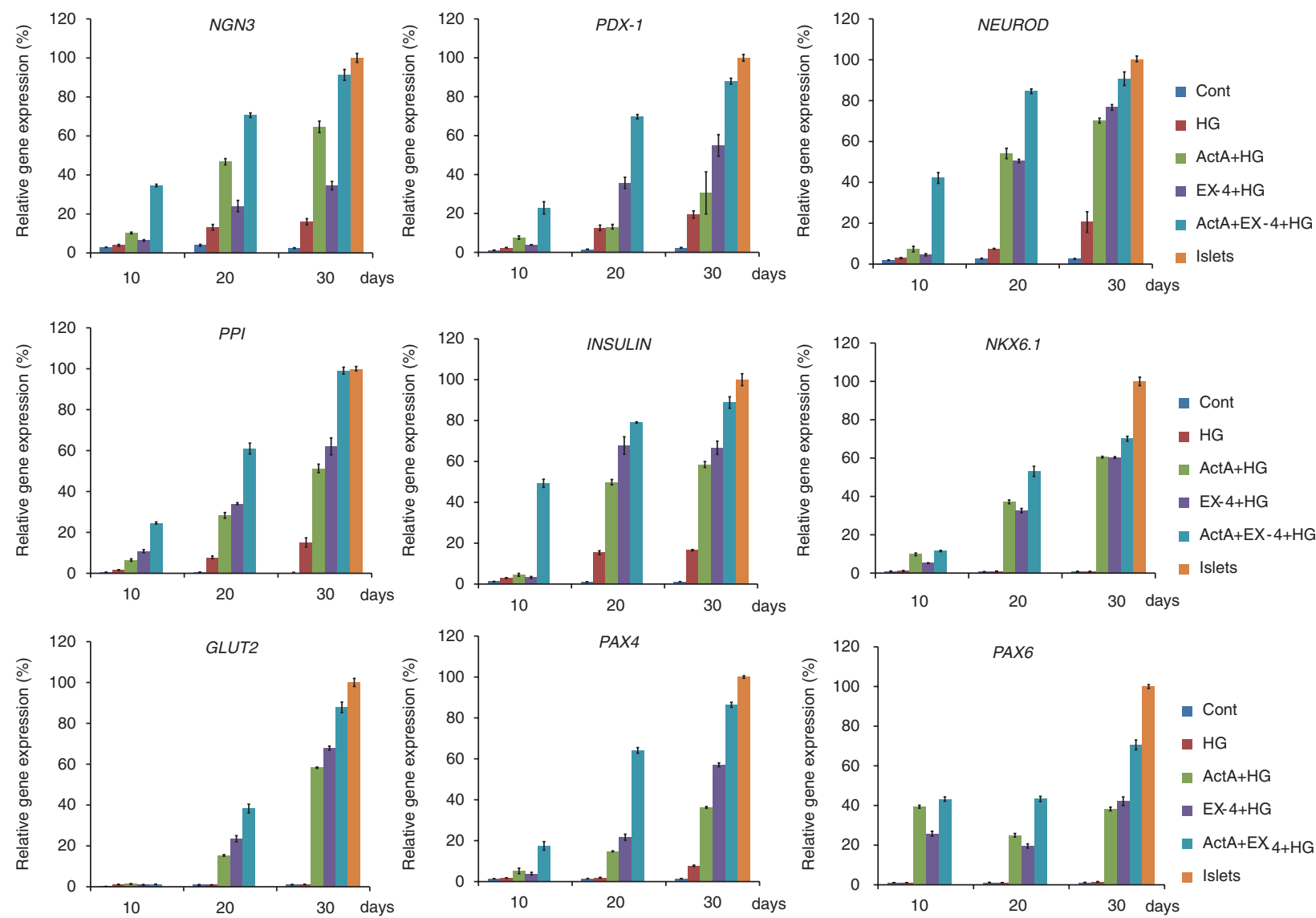

Figure 2

Effects of ActA, EX-4, and glucose on the differentiation of human ductal cells. ActA and EX-4 treatment with $11 \mathrm{mM}$ glucose (HG) stimulated the expression of $\beta$-cell-specific markers in a time-dependent manner. At 30 days of differentiation, co-treatment of cells with ActA, EX-4, and HG induced differentiation of human ductal cells (NGN3: neurogenin 3, PPI: preproinsulin). The $\beta$-cell-specific marker expression of human islets is also presented for comparison with human ductal cells. http://joe.endocrinology-journals.org DOI: $10.1530 / J O E-12-0474$
(C) 2013 Society for Endocrinology Printed in Great Britain
Published by Bioscientifica Ltd 


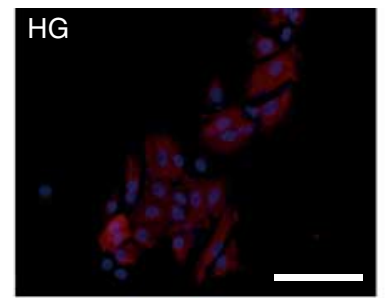

B
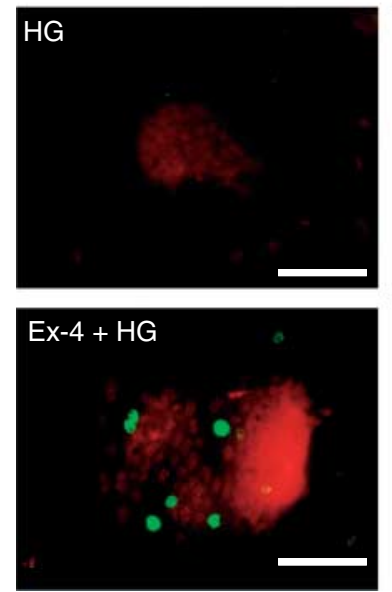
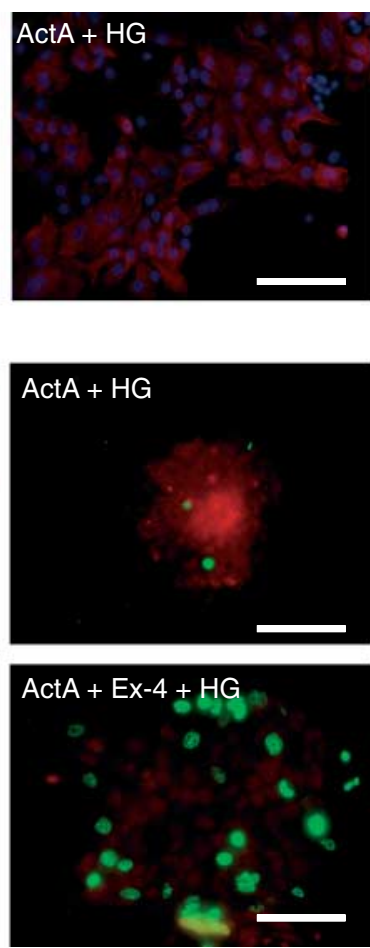
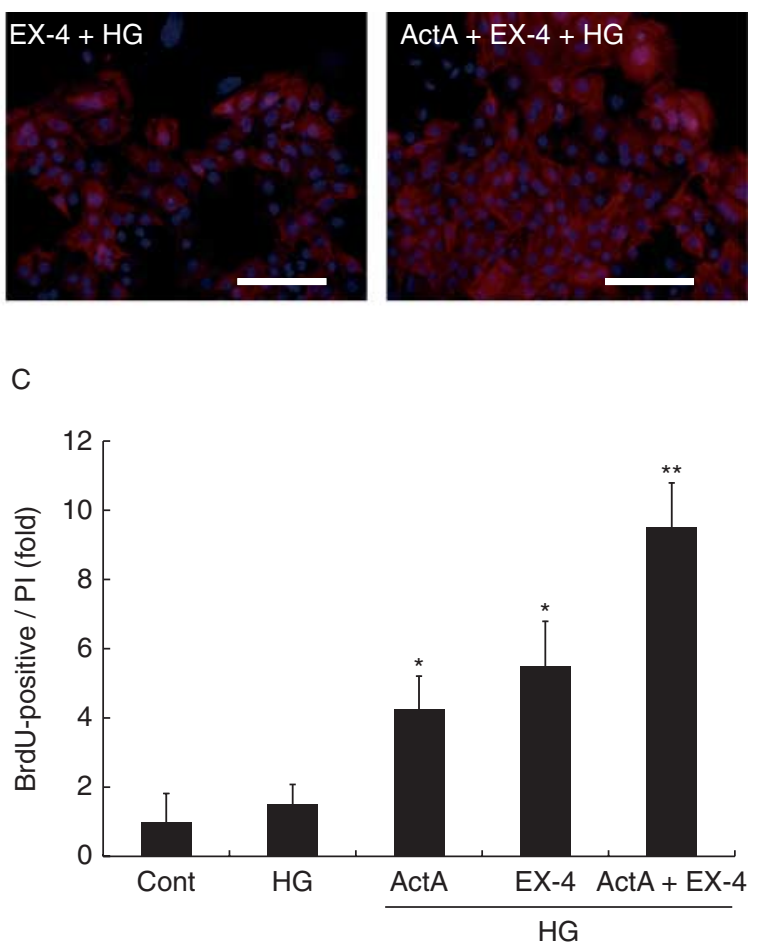

Figure 3

Effects of ActA and EX-4 on the proliferation of human ductal cells. (A) ActA and EX-4 treatment increased the number of human ductal cells at 30 days of differentiation. $\times 400$, scale bar $=100 \mu \mathrm{m}$. (B) Co-treatment of

assay. ActA $(4.25 \pm 0.95)$ or EX-4 $(5.5 \pm 1.29)$ treatment promoted cell proliferation compared with the control group $(1 \pm 0.81)$ and the high-glucose treatment group $(1.5 \pm 0.57)$. Moreover, co-treatment with ActA and EX-4 $(9.5 \pm 1.29)$ promoted greater cell proliferation than treatment with ActA or EX-4 alone (Fig. 3B and C).

\section{Effects of ActA and EX-4 on the differentiation of human pancreatic ductal cells}

Next, we observed PDX1, insulin, and GLUT2 protein expression by immunostaining at 30 days of differentiation. Co-treatment with ActA and EX-4 resulted in upregulation of PDX1, insulin, and GLUT2 expression (Fig. 4A). To determine whether differentiated ductal cells could functionally secrete insulin in response to glucose stimulation, we performed a glucose-induced insulin secretion (GIIS) assay depending on differentiation time $(5,10,15$, 20, and 30 days). ActA and EX-4 treatment significantly stimulated insulin secretion from 20 days of differentiation. Compared with the ActA treatment group, the EX-4-treated ductal cells showed significantly increased cells with ActA and EX-4 further increased cell proliferation. (C) Treatment of cells with ActA and EX-4 also increased BrdU-positive human ductal cells $(n=4, * P<0.05$ vs Cont, HG; $* * P<0.001$ vs Cont, HG, ActA and EX-4).

insulin secretion. Furthermore, co-treatment of cells with ActA and EX-4 resulted in increased insulin secretion from 10 days compared with treatment of cells with $\mathrm{HG}$, ActA, or EX-4 (Fig. 4B). The GIIS ability of differentiated human ductal cells was less than normal islets (Fig. 4C).

\section{Transplantation of human pancreatic ductal cells into STZ-induced diabetic nude mice}

After differentiation (for 30 days), we transplanted human ductal cells into diabetic mice to determine whether these cells could normalize hyperglycemia. After STZ injection, we verified $\beta$-cell destruction by insulin immunostaining and blood glucose measurements (data not shown). Differentiated ductal cells $\left(1 \times 10^{6}\right)$ infected with $1 \times 10^{8}$ pfu adenovirus-GFP were transplanted into the subcapsular spaces of the left kidneys of each group of mice. To determine whether hypoxia was induced in the graft, we performed TUNEL assays on the transplanted grafts 3 days after transplantation. A small number of TUNEL-positive cells were observed in the transplanted sites (Fig. 5A). Blood glucose levels gradually normalized

Published by Bioscientifica Ltd 
A
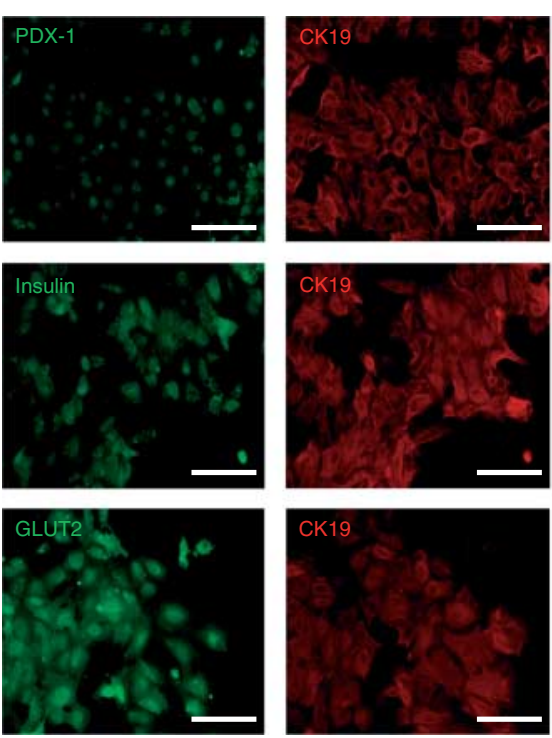
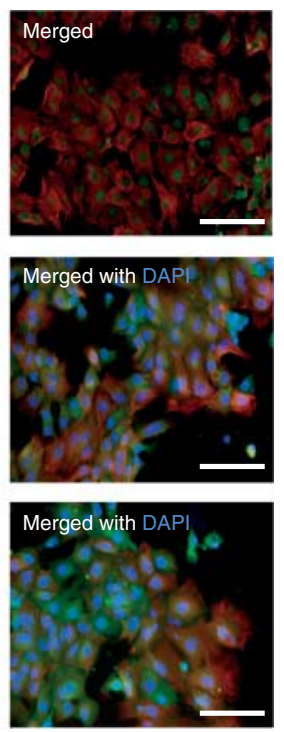

B
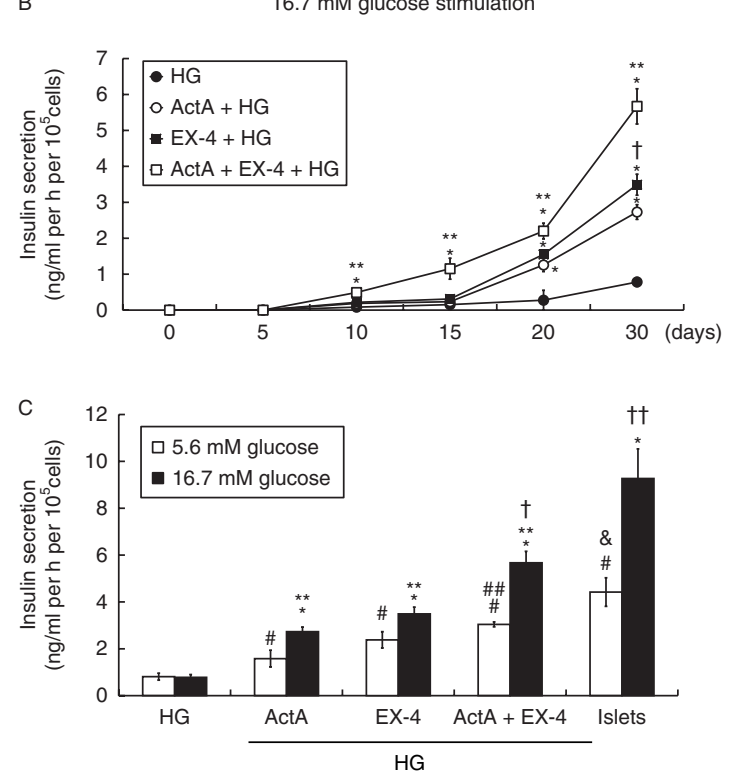

Human ductal cells (30 days)

\section{Figure 4}

Effects of ActA and EX-4 on insulin, PDX1, and GLUT2 protein expression and the GIIS of human ductal cells. (A) At 30 days of differentiation, ActA and EX-4 treatment upregulated the protein expression of PDX1, insulin, and GLUT2. $\times 400$, scale bar $=100 \mu \mathrm{m}$. (B) The insulin secretion at $16.7 \mathrm{mM}$ glucose stimulation was detected by ELISA. Co-treatment of cells with Act A, EX-4, and HG promoted insulin secretion of human ductal cells $(n=4$, ${ }^{*} P<0.05$ vs $\mathrm{HG} ;{ }^{*} * P<0.05$ vs $\mathrm{EX}-4+\mathrm{HG} ;{ }^{\dagger} P<0.001$ vs ActA $+\mathrm{EX}-4+\mathrm{HG}$ ).

in the mice that had received differentiated ductal cell transplants. We injected ActA and EX-4 into diabetic mice at the same time as a control transplantation group. A single injection of ActA and EX-4 transiently decreased blood glucose levels; however, this decrease in blood glucose levels was not maintained. After removal of transplant graft in mice transplanted with differentiated human ductal cells, blood glucose rapidly increased the level before transplantation (Fig. 5B). And then, we examined insulin expression in the graft by immunostaining. Strong expression of insulin was found in GFPpositive cells at the transplant site (Fig. 6A). In addition, angiogenesis was observed by PECAM immunostaining. PECAM-positive blood vessels were located on the insulinexpressing area (Fig. 6B).

\section{Discussion}

In this study, we isolated human pancreatic ductal cells and induced them to differentiate into insulin-producing cells by treating them with ActA and EX-4. In particular, we enriched pure CK19- and CA-19-9-positive human
(C) GIIS ability of differentiated human ductal cells was compared with that of human islets $(n=4, * P<0.05$ vs $5.6 \mathrm{mM}$ glucose; $* * P<0.01$ vs $16.7 \mathrm{mM}$ glucose of HG; ${ }^{\#} P<0.05$ vs $5.6 \mathrm{mM}$ glucose of HG; ${ }^{\# \#} P<0.01$ vs $5.6 \mathrm{mM}$ glucose of ActA + HG; ${ }^{\dagger} P<0.01$ vs $16.7 \mathrm{mM}$ glucose of ActA + HG, EX-4+ HG; ${ }^{\mathrm{t}+} P<0.01$ vs $16.7 \mathrm{mM}$ glucose of $\mathrm{Act} A+\mathrm{EX}-4+\mathrm{HG}$; and ${ }^{\&} P<0.01$ vs $5.6 \mathrm{mM}$ glucose of ActA+EX-4+HG).

ductal cells for differentiation. We treated cells with $5 \mathrm{mM}$ STZ to obtain pure human ductal cells. By treating cells with STZ, we ruled out the possibility that residual $\beta$-cells influenced the differentiation of the human ductal cells. It has been reported that human $\beta$-cells are resistant to STZ. Yang \& Wright (2002) transplanted adult rat, mouse, fish, and human pancreatic islets into nude mice and then injected STZ at different doses. As a result, STZ was not toxic to the adult human islets. However, this study only examined the effects of a single injection of STZ at a dose of up to $450 \mathrm{mg} / \mathrm{kg}$. We used a relatively high concentration of STZ $(5 \mathrm{mM})$ and treated the human ductal cells for 5 days. In addition, Tuch et al. reported that only fetal human islets were resistant to STZ-induced toxicity (Tuch et al. 1989, Tuch \& Chen 1993).

In addition, we removed fibroblast-like cells in human pancreatic tissues by geneticin treatment during the initial stages of culture. Overgrowth of fibroblast-like cells inhibits human ductal cell attachment and growth because these cells have a higher growth rate and they attach earlier than ductal cells. Recent studies reported the switch of cell phenotype in epithelial cell culture, and this

Published by Bioscientifica Ltd. 

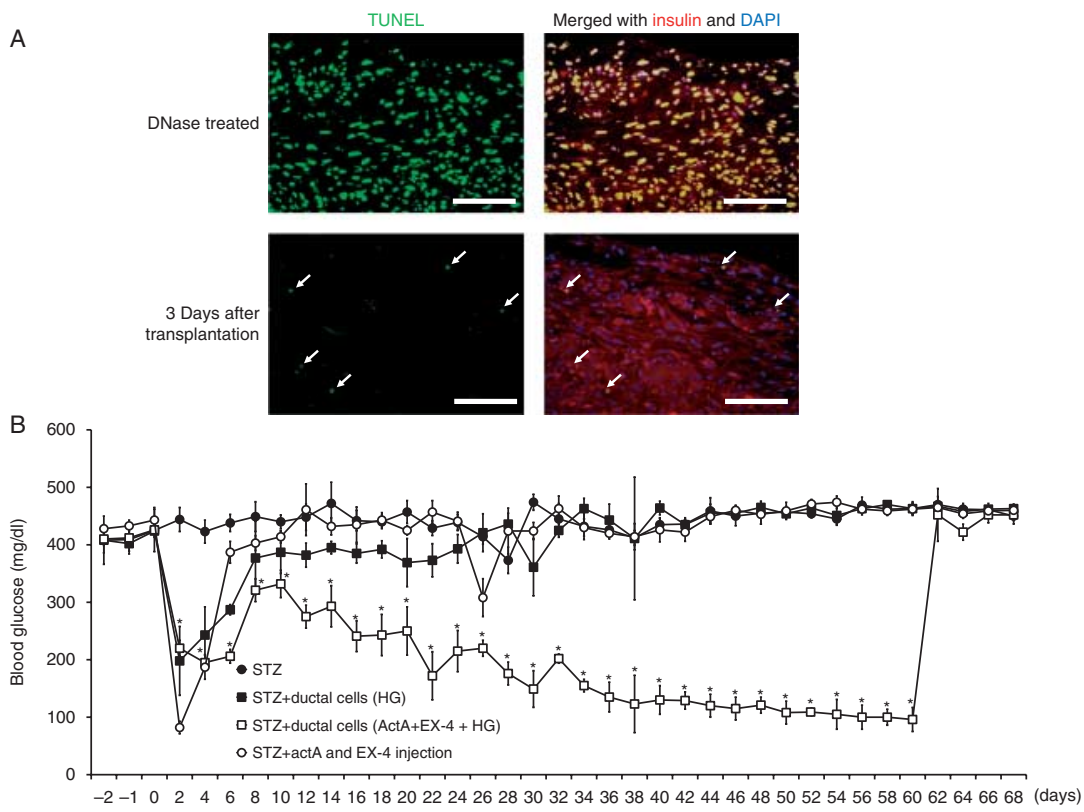

Figure 5

Changes in fasting blood glucose levels and immunohistochemical staining results in STZ-treated nude mice. (A) To identify potential hypoxia-induced apoptosis, a TUNEL assay was performed on the sectioned transplant graft tissue at 3 days after transplantation. A small number of TUNEL-positive cells (green, arrows) were detected at the transplant site compared with the positive control (DNase treated). Tissue sections were counterstained with DAPI. $\times 400$, scale bar $=100 \mu \mathrm{m}$. (B) After transplantation of differentiated human ductal cells $\left(1 \times 10^{6}\right.$ cells), blood glucose levels

change was due to epithelial-mesenchymal transition (EMT). EMT plays an important role in dedifferentiation, proliferation, and redifferentiation of pancreatic epithelial cells (Saika et al. 2004, Ulianich et al. 2008) and may be associated with tissue regeneration in liver and pancreas and cultured human $\beta$-cells (Gershengorn et al. 2004, Ouziel-Yahalom et al. 2006, Russ et al. 2009). EMT is rapidly undergone and most cultured pancreatic epithelial cells changed into fibroblast-like cells. We were trying to rule out this change to verify the differentiation potency of human ductal cells only, so $50 \mu \mathrm{M}$ geneticin were used for elimination of fibroblast-like cells from initial stage of culture. Treatment of geneticin inhibited the morphological change of human ductal cells into fibroblast-like cells and outgrowth. Growth media containing geneticin were used until treatment of ActA, EX-4, and HG, any other fibroblast-like cells were not observed during culture. Human ductal cells can also be isolated by automated magnetic cell sorting (auto-MACS). Gmyr et al. $(2001,2004)$ performed human ductal cell autoMACS using a CA19-9 antibody. In Gmyr's study, geneticin was applied to inhibit the proliferation of gradually normalized ( ${ }^{P} P<0.05$ vs STZ). Closed circle, STZ $(n=5)$ : no transplantation group; open circle, STZ + ActA, and EX-4 injection $(n=5)$ : ActA and EX-4 injection group; closed square, STZ + ductal cells (HG) group $(n=5)$ : ductal cells treated with $11 \mathrm{mM}$ glucose for 30-day transplantation group; open square, STZ + ductal cells (ActA + EX-4+HG) $(n=5)$ : ductal cells co-treated with ActA and EX-4 with HG for 30 day-transplantation group. The transplant graft was removed from all the animals in this group (open square) after 60 days of transplantation.

fibroblast-like cells in the pancreas. This isolation method can potentially be used for the large-scale and rapid isolation of human ductal cells for clinical trials.

Our q-PCR and GIIS results indicate that normal islets have more potent insulin secretory capacity than differentiated human ductal cells. However, treatment with ActA and EX-4 resulted in human ductal cell differentiation.

ActA was known as a differentiation factor for endocrine cell differentiation. Treatment of ActA induces the expression of $N K X 1.1$ and $P A X$ genes in embryonic stem cell-induced embryoid bodies (Yamada et al. 1994) and NGN3 expression in pancreatic acinar AR42-B13 cells (Ogihara et al. 2003). Moreover, ActA promoted PAX4 gene expression in AR42J cells and pancreatic $\beta$-cell line, NIT1, and INS-1 cells (Ueda 2000, Kanno et al. 2006). In addition, it has been reported that EX-4 induced the expressions of $P d x 1$ and Ngn3 in pancreas of STZ-induced diabetic mice (Kodama et al. 2005). These genes have an important role in pancreatic development and endocrine cell differentiation. In this study, treatment of ActA and EX-4 induced these gene expressions in human ductal cells. However, differentiation of human

Published by Bioscientifica Ltd 
A

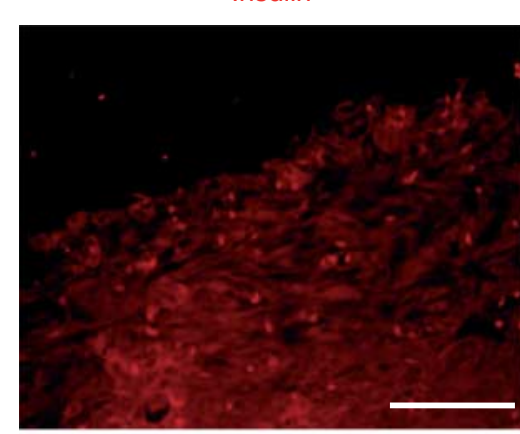

B

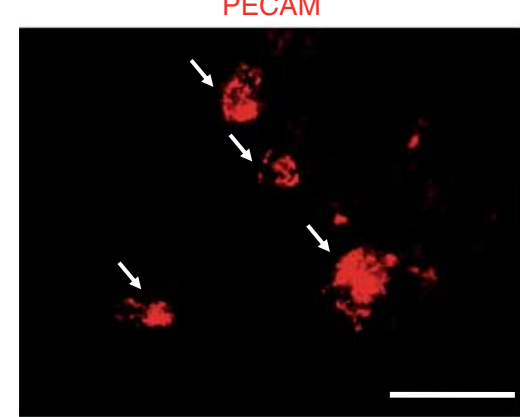

GFP

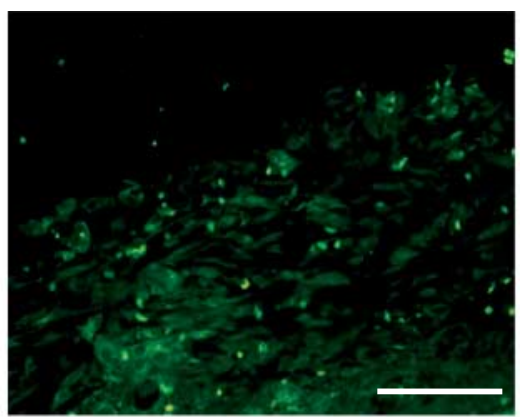

Insulin

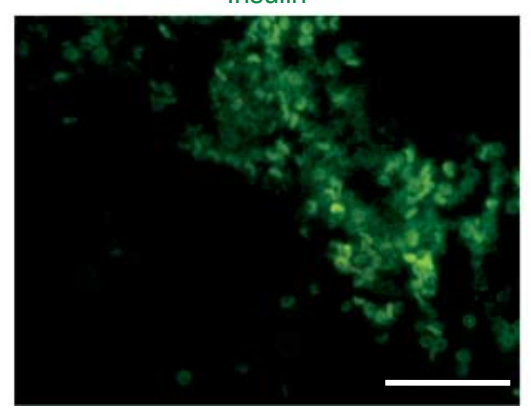

Merged

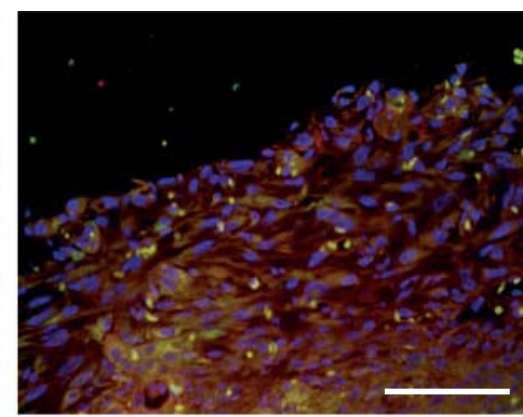

Merged

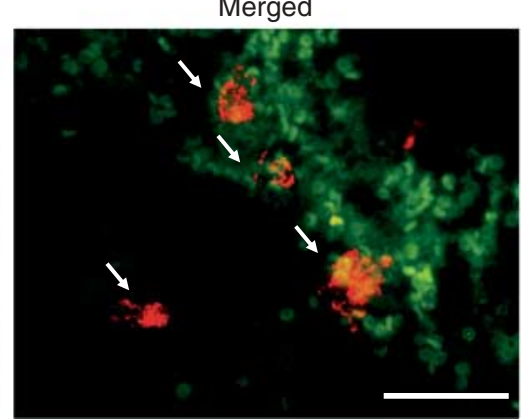

\section{Figure 6}

Histochemical analysis of the transplant graft. (A) At 60 days after transplantation, the transplant grafts were removed and immunostained with insulin antibodies. Differentiated human ductal cells were insulin positive (red) and GFP positive (green). $\times 400$, scale bar $=100 \mu \mathrm{m}$.

ductal cells required a relatively long time. At 10 days of differentiation, expression of insulin gene was detected, but these cells were not functional because GLUT2, which is necessary for insulin secretion in response to glucose stimulation, was not expressed. GLUT2 was expressed only after 20 days of differentiation. In Fig. 4A, $\beta$-cell-specific markers, PDX1, insulin, and GLUT2, were detected; however, CK19 was still expressed. This result suggests that these ductal cells are still in differentiation progress and are not fully differentiated. In the results of the $\beta$-cellspecific gene expression analysis and GIIS assay with differentiated human ductal cells, functions of differentiated human ductal cells were less than normal islets (Figs 2 and 4C). Complete full differentiation of human ductal cells and a reduction in the period required for differentiation would make human ductal cells an attractive alternative to islet transplantation for treating diabetes.

This is the first study to report the transplant of differentiated human ductal cells into diabetic animals and the induction of normal glycemic control as a result. Interestingly, the human ductal cells treated with HG $(11 \mathrm{mM})$ that were only transplanted into the diabetic animals induced a transient reduction in blood glucose
(B) PECAM (red) and insulin (green) double staining in the transplant graft was assessed to monitor angiogenesis. PECAM-positive signals (red) were located nearby the insulin-positive site (arrows). $\times 1000$, scale bar $=40 \mu \mathrm{m}$.

levels (Fig. 5B). We applied HG in vitro for differentiation. In a study using a human pancreatic duct cell line, PANC 1 cells, serum-free media with a high-glucose concentration induced low levels of islet hormone mRNA and protein expression (Hardikar et al. 2003). In this study, high-glucose treatment also induced the expression of $\beta$-cell-specific markers (Fig. 2). However, the expression levels of these genes were lower than the expression levels observed in the other treatment groups.

To compare the glucose-lowering effects of differentiated human ductal cells, we co-injected ActA and EX-4 into diabetic mice, which resulted in a transient decrease in their blood glucose levels. It has been reported that injection of ActA and betacellulin induced persistently improved glucose homeostasis in a STZ-treated newborn mouse because ActA and betacellulin upregulated the proliferation and differentiation of $\beta$-cells, $\delta$-cells, and ductal cells (Li et al. 2004). In addition, EX-4 treatment has been reported to stimulate $\beta$-cell neogenesis and improve glucose homeostasis (Xu et al. 1999, Tourrel et al. 2001). However, these results were achieved by the repeated injection of ActA, betacellulin, and EX-4. Consistent with the previous studies, we found that a single injection of

Published by Bioscientifica Ltd 
ActA and EX-4 did not induce stable glucose homeostasis. The transient blood glucose-lowering effect may be due to the effects of EX-4 rather than the effects of ActA. We plan to further study the effects of ActA and EX-4 combination therapy in diabetic animals.

According to Zhang et al. (1996) and Ichikawa et al. (2001), ActA reduces DNA synthesis and growth of hepatocytes. However, ActA had no effects on cell proliferation and apoptosis of human ductal cells in our study. By contrast, ActA treatment upregulated cell proliferation (Fig. 3). These results suggest that ActA has different effects in different cell types. We collected pancreatic tissues from diabetic mice single injected with ActA and EX-4 and then performed the TUNEL assay to detect apoptosis. We found no significant difference in apoptosis between the control group and the ActA- and EX-4-injected groups.

At 3 days after transplantation, the grafts were isolated for TUNEL assay to determine whether the injection of a large amount of ductal cells $\left(1 \times 10^{6}\right.$ cells) caused hypoxia at the transplantation site. However, a small number of apoptotic cells were detected in the grafts. In addition, we performed insulin and PECAM double immunostaining to identify angiogenesis at 60 days after transplantation. As shown in Fig. 6B, PECAM-positive signals overlapped with insulin-positive cells. This result suggests that angiogenesis was induced at the transplant sites and that insulin secretion in response to glucose was achieved after human ductal cell transplantation.

Cellular replacement therapy is a promising treatment option for long-term blood glucose control in diabetes mellitus. However, islet transplantation is limited by the amount of available tissue. To overcome the limited donor supply, diverse therapeutic approaches such as in vitro islet mass expansion, xenotransplantation, and stem cell technology have been widely investigated. In this study, we have shown that it is possible to replace islet cells with human ductal cells obtained from the residual pancreatic tissue after islet isolation. Furthermore, we evaluated the normoglycemic effects of differentiated human ductal cells stimulated with ActA, EX-4, and glucose in a diabetic animal model for the first time. Our results suggest that human pancreatic ductal cells induced to differentiate by ActA, EX-4, and glucose treatment are a promising therapeutic option for diabetes treatment.

\section{Declaration of interest}

The authors declare that there is no conflict of interest that could be perceived as prejudicing the impartiality of the research reported.

\section{Funding}

This work was supported by a grant from the Ministry of Health and Welfare, Republic of Korea (A084065).

\section{References}

Beattie GM, Itkin-Ansari P, Cirulli V, Leibowitz G, Lopez AD, Bossie S, Mally MI, Levine F \& Hayek A 1999 Sustained proliferation of PDX-1 + cells derived from human islets. Diabetes 48 1013-1019. (doi:10.2337/diabetes.48.5.1013)

Bonner-Weir S \& Weir GC 2005 New sources of pancreatic $\beta$-cells. Nature Biotechnology 23 57-861. (doi:10.1038/nbt1115)

Bonner-Weir S, Toschi E, Inada A, Reitz P, Fonseca SY, Aye T \& Sharma A 2004 The pancreatic ductal epithelium serves as a potential pool of progenitor cells. Pediatric Diabetes 5(Suppl 2) 16-22. (doi:10.1111/ j.1399-543X.2004.00075.x)

Brelje TC, Scharp DW, Lacy PE, Ogren L, Talamantes F, Robertson M, Friesen HG \& Sorenson RL 1993 Effect of homologous placental lactogens, prolactins, and growth hormones on islet $\beta$-cell division and insulin secretion in rat, mouse, and human islets: implication for placental lactogen regulation of islet function during pregnancy. Endocrinology 132 879-887. (doi:10.1210/en.132.2.879)

Chen YE \& Drucker DJ 1997 Tissue-specific expression of unique mRNAs that encode proglucagon-derived peptides or exendin 4 in the lizard. Journal of Biological Chemistry 272 4108-4115. (doi:10.1074/ jbc.272.7.4108)

Drucker DJ 1998 Glucagon-like peptides. Diabetes 47 159-169. (doi:10.2337/diabetes.47.2.159)

Drucker DJ 2002 Biological actions and therapeutic potential of the glucagon-like peptides. Gastroenterology 122 531-544. (doi:10.1053/ gast.2002.31068)

Gershengorn MC, Hardikar AA, Wei C, Geras-Raaka E, Marcus-Samuels B \& Raaka BM 2004 Epithelial-to-mesenchymal transition generates proliferative human islet precursor cells. Science 306 2261-2264. (doi:10.1126/science.1101968)

Gmyr V, Kerr-Conte J, Vandewalle B, Proye C, Lefebvre J \& Pattou F 2001 Human pancreatic ductal cells: large-scale isolation and expansion. Cell Transplantation 10 109-121.

Gmyr V, Belaich S, Muharram G, Lukowiak B, Vandewalle B, Pattou F \& Kerr-Conte J 2004 Rapid purification of human ductal cells from human pancreatic fractions with surface antibody CA19-9. Biochemical and Biophysical Research Communications 320 27-33. (doi:10.1016/ j.bbrc.2004.05.125)

Goke R, Fehmann HC, Linn T, Schmidt H, Krause M, Eng J \& Göke B 1993 Exendin- 4 is a high potency agonist and truncated exendin-(9-39)amide an antagonist at the glucagon-like peptide 1-(7-36)-amide receptor of insulin-secreting $\beta$-cells. Journal of Biological Chemistry $\mathbf{1 5}$ 19650-19655.

Greig NH, Holloway HW, De Ore KA, Jani D, Wang Y, Zhou J, Garant MJ \& Egan JM 1999 Once daily injection of exendin-4 to diabetic mice achieves long-term beneficial effects on blood glucose concentrations. Diabetologia 42 45-50. (doi:10.1007/s001250051111)

Gutniak M, Orskov C, Holst JJ, Ahren B \& Efendic S 1992 Antidiabetogenic effect of glucagon-like peptide-1 (7-36)amide in normal subjects and patients with diabetes mellitus. New England Journal of Medicine 326 1316-1322. (doi:10.1056/NEJM199205143 262003)

Hardikar AA, Marcus-Samuels B, Geras-Raaka E, Raaka BM \& Gershengorn MC 2003 Human pancreatic precursor cells secrete FGF2 to stimulate clustering into hormone-expressing islet-like cell aggregates. PNAS 100 7117-7122. (doi:10.1073/pnas.1232230100)

Hemmati-Brivanlou A \& Melton DA 1994 Inhibition of activin receptor signaling promotes neuralization in Xenopus. Cell 77 273-281. (doi:10.1016/0092-8674(94)90319-0) 
Ichikawa T, Zhang YQ, Kogure K, Hasegawa Y, Takagi H, Mori M \& Kojima I 2001 Transforming growth factor $\beta$ and activin tonically inhibit DNA synthesis in the rat liver. Hepatology 34 918-925. (doi:10.1053/jhep. 2001.29132)

Kanno R, Ogihara T, Igarashi Y, Tanaka Y, Smith SB, Kojima I, German MS, Kawamori R \& Watada H 2006 Activin A-induced expression of PAX4 in AR42J-B13 cells involves the increase in transactivation of E47/E12. Biochimica et Biophysica Acta 1759 44-50. (doi:10.1016/ j.bbaexp.2006.01.004)

Knudsen LB \& Pridal L 1996 Glucagon-like peptide-1-(9-36) amide is a major metabolite of glucagon-like peptide-1-(7-36) amide after in vivo administration to dogs, and it acts as an antagonist on the pancreatic receptor. European Journal of Pharmacology 318 429-435. (doi:10.1016/ S0014-2999(96)00795-9)

Kodama S, Toyonaga T, Kondo T, Matsumoto K, Tsuruzoe K, Kawashima J, Goto H, Kume K, Kume S, Sakakida M et al. 2005 Enhanced expression of PDX-1 and Ngn 3 by exendin-4 during $\beta$ cell regeneration in STZ-treated mice. Biochemical and Biophysical Research Communications 327 1170-1178. (doi:10.1016/j.bbrc.2004.12.120)

Lefebvre VH, Otonkoski T, Ustinov J, Huotari MA, Pipeleers DG \& Bouwens L 1998 Culture of adult human islet preparations with hepatocyte growth factor and $804 \mathrm{G}$ matrix is mitogenic for duct cells but not for $\beta$-cells. Diabetes 47 134-137. (doi:10.2337/diabetes. 47.1.134)

Li L, Yi Z, Seno M \& Kojima I 2004 Activin A and betacellulin: effect on regeneration of pancreatic $\beta$-cells in neonatal streptozotocin-treated rats. Diabetes 53 608-615. (doi:10.2337/diabetes.53.3.608)

Maehr R, Chen S, Snitow M, Ludwig T, Yagasaki L, Goland R, Leibelc RL \& Melton DA 2009 Generation of pluripotent stem cells from patients with type 1 diabetes. PNAS 106 15768-15773. (doi:10.1073/ pnas.0906894106)

Mashima H, Ohnishi H, Wakabayashi K, Mine T, Miyagawa J, Hanafusa T, Seno M, Yamada H \& Kojima I 1996 Betacellulin and activin A coordinately convert amylase-secreting pancreatic AR42J cells into insulin-secreting cells. Journal of Clinical Investigation 97 1647-1654. (doi:10.1172/JCI118591)

Mojsov S, Weir GC \& Habener JF 1987 Insulinotropin: glucagon-like peptide I (7-37) co-encoded in the glucagon gene is a potent stimulator of insulin release in the perfused rat pancreas. Journal of Clinical Investigation 79 616-619. (doi:10.1172/JCI112855)

Moriya N, Komazaki S, Takahashi S, Yokota C \& Asashima M 2000 In vitro pancreas formation from Xenopus ectoderm treated with activin and retinoic acid. Development, Growth \& Differentiation 42 593-602. (doi:10.1046/j.1440-169x.2000.00542.x)

Nauck MA, Heimesaat MM, Orskov C, Holst JJ, Ebert R \& Creutzfeldt W 1993 Preserved incretin activity of glucagon-like peptide 1 [7-36 amide] but not of synthetic human gastric inhibitory polypeptide in patients with type-2 diabetes mellitus. Journal of Clinical Investigation 91 301-307. (doi:10.1172/JCI116186)

Ogihara T, Watada H, Kanno R, Ikeda F, Nomiyama T, Tanaka Y, Nakao A, German MS, Kojima I \& Kawamori R 2003 p38 MAPK is involved in activin A- and hepatocyte growth factor-mediated expression of pro-endocrine gene neurogenin 3 in AR42J-B13 cells. Journal of Biological Chemistry 278 21693-21700. (doi:10.1074/ jbc.M302684200)

Ouziel-Yahalom L, Zalzman M, Anker-Kitai L, Knoller S, Bar Y, Glandt M, Herold K \& Efrat S 2006 Expansion and redifferentiation of adult human pancreatic islet cells. Biochemical and Biophysical Research Communications 341 291-298. (doi:10.1016/ j.bbrc.2005.12.187)

Park MK, Han C, Lee KH, Hong SH, Kim HS, Lee YJ, Jeong IK, Noh JH, Yang TY, Lee MS et al. 2007 Effects of activin A on pancreatic ductal cells in streptozotocin-induced diabetic rats. Transplantation 83 925-930. (doi:10.1097/01.tp.0000259978.62139.9d)
Ricordi C, Lacy PE, Finke EH, Olack BJ \& Scharp DW 1988 Automated method for isolation of human pancreatic islets. Diabetes 37 413-420. (doi:10.2337/diabetes.37.4.413)

Ricordi C, Gray DW, Hering BJ, Kaufman DB, Warnock GL, Kneteman NM, Lake SP, London NJ, Socci C, Alejandro R et al. 1990 Islet isolation assessment in man and large animals. Acta Diabetologica Latina 27 185-195. (doi:10.1007/BF02581331)

Robertson GS, Chadwick DR, Contractor H, James RF, Bell PR \& London NJ 1993 The use of continuous density gradients for the assessment of islet and exocrine tissue densities and islet purification. Acta Diabetologica 30 175-180. (doi:10.1007/BF00572864)

Russ HA, Ravassard P, Kerr-Conte J, Pattou F \& Efrat S 2009 Epithelialmesenchymal transition in cells expanded in vitro from lineage-traced adult human pancreatic $\beta$ cells. PLoS ONE 4 e6417. (doi:10.1371/ journal.pone.0006417)

Saika S, Kono-Saika S, Tanaka T, Yamanaka O, Ohnishi Y, Sato M, Muragaki Y, Ooshima A, Yoo J, Flanders KC et al. 2004 Smad3 is required for dedifferentiation of retinal pigment epithelium following retinal detachment in mice. Laboratory Investigation 84 1245-1258. (doi:10.1038/labinvest.3700156)

Sudre B, Broqua P, White RB, Ashworth D, Evans DM, Haigh R, Junien JL \& Aubert ML 2002 Chronic inhibition of circulating dipeptidyl peptidase IV by FE 999011 delays the occurrence of diabetes in male zucker diabetic fatty rats. Diabetes $\mathbf{5 1}$ 1461-1469. (doi:10.2337/ diabetes.51.5.1461)

Tateishi K, He J, Taranova O, Liang G, D'Alessio AC \& Zhang Y 2008 Generation of insulin-secreting islet-like clusters from human skin fibroblasts. Journal of Biological Chemistry 283 31601-31607. (doi:10.1074/jbc.M806597200)

Thorens B, Porret A, Buhler L, Deng SP, Morel P \& Widmann C 1993 Cloning and functional expression of the human islet GLP-1 receptor. Demonstration that exendin-4 is an agonist and exendin-(9-39) an antagonist of the receptor. Diabetes 42 1678-1682. (doi:10.2337/ diabetes.42.11.1678)

Todd JF, Wilding JP, Edwards CM, Khan FA, Ghatei MA \& Bloom SR 1997 Glucagon-like peptide-1 (GLP-1): a trial of treatment in non-insulindependent diabetes mellitus. European Journal of Clinical Investigation $\mathbf{2 7}$ 533-536. (doi:10.1046/j.1365-2362.1997.1490691.x)

Tourrel C, Bailbe D, Meile MJ, Kergoat M \& Portha B 2001 Glucagon-like peptide- 1 and exendin- 4 stimulate $\beta$-cell neogenesis in streptozotocintreated newborn rats resulting in persistently improved glucose homeostasis at adult age. Diabetes 50 1562-1570. (doi:10.2337/ diabetes.50.7.1562)

Tuch BE \& Chen J 1993 Resistance of the human fetal $\beta$-cell to the toxic effect of multiple low-dose streptozotocin. Pancreas 8 305-311. (doi:10.1097/00006676-199305000-00004)

Tuch BE, Turtle JR \& Simeonovic CJ 1989 Streptozotocin is not toxic to the human fetal $\beta$-cell. Diabetologia 32 678-684. (doi:10.1007/ BF00274256)

Ueda Y 2000 Activin A increases Pax4 gene expression in pancreatic $\beta$ cell lines. FEBS Letters 480 101-105. (doi:10.1016/S0014-5793(00) 01914-1)

Ulianich L, Garbi C, Treglia AS, Punzi D, Miele C, Raciti GA, Beguinot F, Consiglio E \& Di Jeso B 2008 ER stress is associated with dedifferentiation and an epithelial-to-mesenchymal transition-like phenotype in PC CI3 thyroid cells. Journal of Cell Science 121 477-486. (doi:10.1242/ jcs.017202)

Xu G, Stoffers DA, Habener JF \& Bonner-Weir S 1999 Exendin-4 stimulates both $\beta$-cell replication and neogenesis, resulting in increased $\beta$-cell mass and improved glucose tolerance in diabetic rats. Diabetes $\mathbf{4 8}$ 2270-2276. (doi:10.2337/diabetes.48.12.2270)

Yamada G, Kioussi C, Schubert FR, Eto Y, Chowdhury K, Pituello F \& Gruss P 1994 Regulated expression of Brachyury(T), Nkx1.1 and Pax genes in embryoid bodies. Biochemical and Biophysical Research Communications 199 552-563. (doi:10.1006/bbrc.1994.1264) 
Yamaoka T, Idehara C, Yano M, Matsushita T, Yamada T, Ii S, Moritani M, Hata J, Sugino H, Noji S et al. 1998 Hypoplasia of pancreatic islets in transgenic mice expressing activin receptor mutants. Journal of Clinical Investigation 102 294-301. (doi:10.1172/ JCI2769)

Yang H \& Wright JR Jr 2002 Human $\beta$ cells are exceedingly resistant to streptozotocin in vivo. Endocrinology 143 2491-2495. (doi:10.1210/ en.143.7.2491REF5=10.1074/jbc.272.7.4108)

Yuan S, Rosenberg L, Paraskevas S, Agapitos D \& Duguid WP 1996 Transdifferentiation of human islets to pancreatic ductal cells in collagen matrix culture. Differentiation 61 67-75. (doi:10.1046/ j.1432-0436.1996.6110067.x)
Yue F, Cui L, Johkura K, Ogiwara N \& Sasaki K 2006 Glucagon-like peptide-1 differentiation of primate embryonic stem cells into insulin-producing cells. Tissue Engineering 12 2105-2116. (doi:10.1089/ten.2006.12.2105)

Zhang YQ, Kanzaki M, Mashima H, Mine T \& Kojima I 1996 Norepinephrine reverses the effects of activin A on DNA synthesis and apoptosis in cultured rat hepatocytes. Hepatology 23 288-293. (doi:10.1002/hep.510230214)

Zhang D, Jiang W, Liu M, Sui X, Yin X, Chen S, Shi Y \& Deng H 2009 Highly efficient differentiation of human ES cells and iPS cells into mature pancreatic insulin-producing cells. Cell Research 19 429-438. (doi:10.1038/cr.2009.28)

Received in final form 15 February 2013

Accepted 15 March 2013

Accepted Preprint published online 15 March 2013
Published by Bioscientifica Ltd. 